\title{
Motorcycle in the West Java Province, Indonesia: Its Growth and Characteristics
}

\author{
Joewono, T.B. ${ }^{1}$, Lauw B.Z. ${ }^{2}$, and Hendy, H. ${ }^{2}$
}

\begin{abstract}
Motorcycle provides several positive aspects in providing mobility, but its rapid increase in ownership and usage should be anticipated. The West Java Province has the highest number of population in Indonesia, which is potential to have the highest number of motorcycle. This study aims to develop a prediction model of motorcycle number and to develop a model of motorcycle ownership. Two models are proposed to predict the motorcycle growth in West Java, with gross regional domestic product and number of population as the independent variables. Four ordered probit models are proposed to explain motorcycle ownership in Bandung City based on economic, personal, user's travel behavior, and motorcycle characteristics. This study explains that the increase of motorcycle ownership was not influenced by economic condition only, but also by travel behavior and their activity. Thus, besides economic aspects, the anticipation should also be based on travel and activity changes of the user.
\end{abstract}

Keywords: Characteristics, modeling, motorcycle ownership, motorcycle growth.

\section{Introduction}

In 2010, West Java Province has the highest number of population, i.e. as much as 43.053 .732 people [1]. West Java is number two after the DKI Jakarta in term of population density in Indonesia. This high population density is followed by rapid pace of development. The need to travel will increase along with the development of the region [2], thus West Java faces a high increase in number of mobility demand. The increased demand is shown by the increase of vehicle ownership including motorcycle.

Motorcycle becomes an alternative transport mode for people in developing countries, including Indonesia. The low performance of public transport, high mobility of motorcycle, and affordable price of motorcycle become reasons for people to choose motorcycle as their mode of transport [3]. It occurs that people buy motorcycles before buying car when incomes become higher [4]. As a matter of fact, the ownership of motorcycle in the Province of West Java is eight people per unit [1], while the share of motorcycle is $71.69 \%$ compared with all motorized vehicle [5]. The proportion of two - wheel and fourwheel vehicles in Bandung, capital city of West Java, were $57.17 \%$ (296,230 units) and 42.83\% (221,942 units), respectively [4].

\footnotetext{
${ }^{1}$ Graduate Program, Parahyangan Catholic University, Bandung, INDONESIA Email:vftribas@unpar.ac.id

${ }^{2}$ Department of Civil Engineering, Faculty of Engineering, Parahyangan Catholic University, Bandung, INDONESIA
}

Note: Discussion is expected before June, $1^{\text {st }} 2013$, and will be published in the "Civil Engineering Dimension" volume 15, number 2, September 2013.

Received 5 September 2011; revised 20 July 2012; accepted 21 November 2012
In countries with rapid economic growth, the problem of motorcycle growth becomes an important issue [6]. The growth of the number of motorcycle affects the interaction of various types of vehicles and interaction of travel as well. This significant increase of motorcycle causes many problems, namely the increase of accident rate [7], decreasing speed, and increasing time delay for other road users [8].

There are several studies in modeling the growth of vehicle ownership, which mainly focused on car $[6,9$, 10,11]. In modeling the growth of motorcycle, several studies have been done in Asian countries. As an example, comparison of motorcycle ownership behavior in Hanoi, Vietnam, with other countries [12]; dynamic discrete choice models to express the motorcycle ownership behavior and household response to policy [13]; documentation of the changes in motorcycle ownership, motorcyclist mortality, and injury rates in China since 1987 [14]; investigation of the characteristics of motorcycle ownership and car ownership in three typical cities in Taiwan $[15,16]$. In Indonesia, there are very limited studies focusing on motorcycle ownership, while Petragradia et al. [4] and Putranto et al. [17] are the exception, comprehensive research has not been conducted in Indonesia [17].

This study aims to build a prediction model regarding the number of motorcycle in West Java, Indonesia. This study will also elaborate the motorcycle ownership using dataset from Bandung, the capital city of West Java. 


\section{The Growth of Motorcycle}

In developing countries of Asian region, the most significant growth is motorcycle. Number of motorcycle sales in Indonesia reached 5,851,962 units in 2009, while in 2008 the number was $6,215,865$ units [18]. In 2008, the increase of the production of motorcycle in Indonesia was $33.3 \%$ with a total production of 6.27 million units [8].

It is a result of the increasing income in developing countries [19] and the low performance of existing public transportation. Lubis [20] said the reasons for people to use motorcycle are; saving, flexibility, poor quality service of public transporttation, and the easiness to obtain. Saving is the main reason for people to choose motorcycle, as its fuel consumption is really efficient compared with other motorized mode of transport. It is easily understood that economic aspect becomes the main consideration, as Indonesia has a high proportion of low income group. Since the ratio of motorcycle ownership in Indonesia is still relatively low in ASEAN region and motorcycle industry in Indonesia is a growing industry, the potential growth of production is still very good in the future [20]. Moreover, Leong and Sadullah [21] and Petragradia et al. [4] stated that the significant affecting factors in the increase of motorcycle ownership are monthly household income, car ownership, number of family members who have car driving license and or motorcycle driving license, and number of family members. Senbil et al. [22] also stated that the increase amount of income is followed by the increase of private car ownership together with the increase of motorcycle ownership.

Special attention needs to be addressed to the growth of motorcycle, since the growth of motorcycle results in several transportation problems. First problem is high increase of congestion which causes the second problem, namely air pollution. The third problem is a long distance and high travel cost paid by the community with low income. Even though not all problems exist at present, but it will become a big problem in the future [23]. Beside those effects, Ingram and Liu [24] also stated that motorcycle ownership can also reduce the use of public transport. Leong and Sadullah [21] described the interruption caused by motorcycle, while Gentile [25] explained the weak ability of motorcycle in avoiding accident. Data published by the Police of Republic of Indonesia showed that the number of accidents caused by motorcycles increased threefold in 20002005, as much as 19,000 cases [20]. In Denpasar the capital of Bali Province, motorcycle accident contributes to about $80 \%$ of total road accidents. Out of those motorcycle accidents, $32 \%$ are fatal accidents [26]. Zhang et al. [14] reported that in China, motorcyclist fatalities and injuries increased 5.5-fold and 9.3-fold, respectively, between 1987 and 2001. Health data show that motorcycle accidents, which are more than car accidents, results in significant mental health problems, from depression up to disorders due to trauma and stress [27].

\section{Study Area}

Population of the West Java Province in 2009 was $42,693,951$ people, where $50.39 \%$ of them were men [28]. From 1990 up to 2009, the population has increased from 31 million to 42 million (Figure 1). Gross Regional Domestic Product (GRDP) per capita at current prices in 2007 reached Indonesian Rupiah (IDR) 14,309,520.21 with mid-year population as much as 42,099,284 people. In the last twenty years, the GRDP per capita has increased around 16-fold (Figure 2). On the other hand, the growth of motorcycle in the last five years shows a drastic change as appears in Figure 3, while the growth rate of car changes much slower than motorcycle. As a note, these data excludes Banten.

Bandung, the capital city of West Java, has an area of $167.29 \mathrm{~km}^{2}$. In $2009,1,210,164$ people out of $2,374,198$ people were male. The population growth rate (PGR) was $1.90 \%$ and the average population density of Bandung was 14,190.41 people/ $/ \mathrm{km}^{2}$ [28].

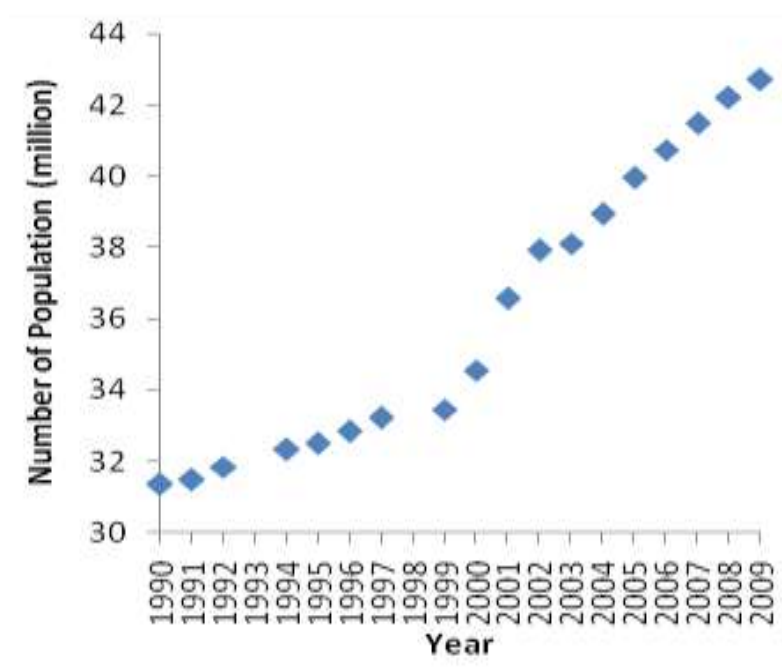

Figure 1. Number of Population in the Province of West Java [28]

\section{Model Estimation of Number of Motorcycle}

According to several studies on the growth of motorcycle $[4,6,17,29]$, there are many influencing factors, e.g.; GRDP, road length, annual rainfall, number of family members, income per capita, distance, and population [30]. Unfortunately there is a limitation on data availability to explain the motorization. In this study, the Authors were only able to collect time series data on number of motorized vehicle, population, and GRDP [30]. 
Using the available aggregate data of all cities and regencies from Badan Pusat Statistik of West Java in the period of 1988-2009 [28], a multiple linear regression was built. Several multiple linear regression models with different specification have been estimated. The best three were presented in Table 1 . Table 1 presents two models with single predictor (Model 1 and Model 2) and one model with two predictors (Model 3). Besides the coefficients (B), the table also provides statistical parameters ( $\mathrm{t}$ statistic and p-value) to explain the fitness as well as its confidence interval. All models have very low $\mathrm{p}$ value of ANOVA ( $F$ test), which implies that linear regression is fit. Model 3 has one variable that is not significant and has the highest coefficient of determination $\left(\mathrm{R}^{2}\right)$. It shows that model with single predictor (Model 1 and Model 2) have a better result. Moreover, based on the value of Mean Square Error (MSE), model with population as dependent variable (Model 1) seems to perform better. By observing the value of parameter estimate in the Model 1, it can be inferred that number of motorcycle in West Java Province will increase by 55 for an addition of 1000 people, while from Model 2, the number of motorcycle in this province will increase by 356,000 units when there is an increase of GRDP as much as one million IDR.

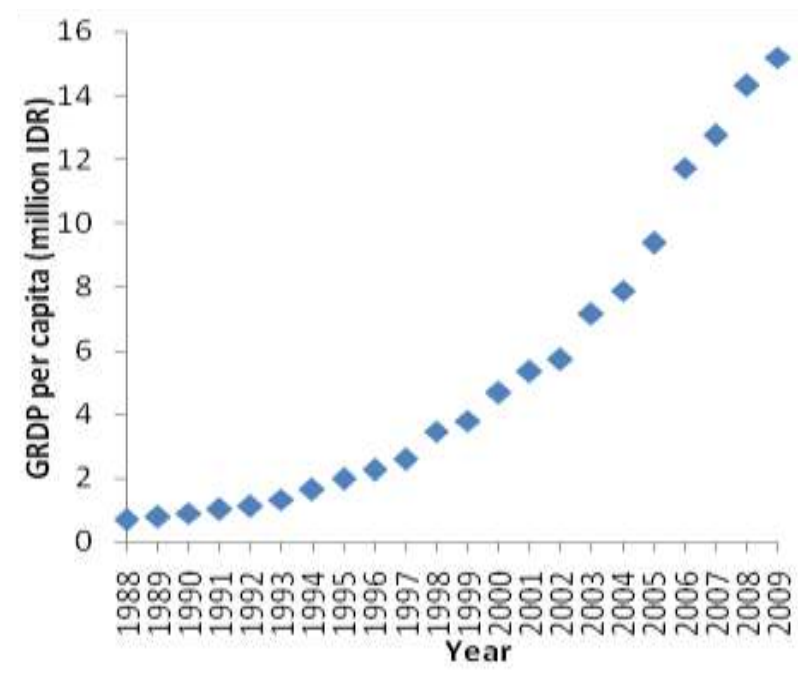

Figure 2. GRDP per capita in the Province of West Java [28]

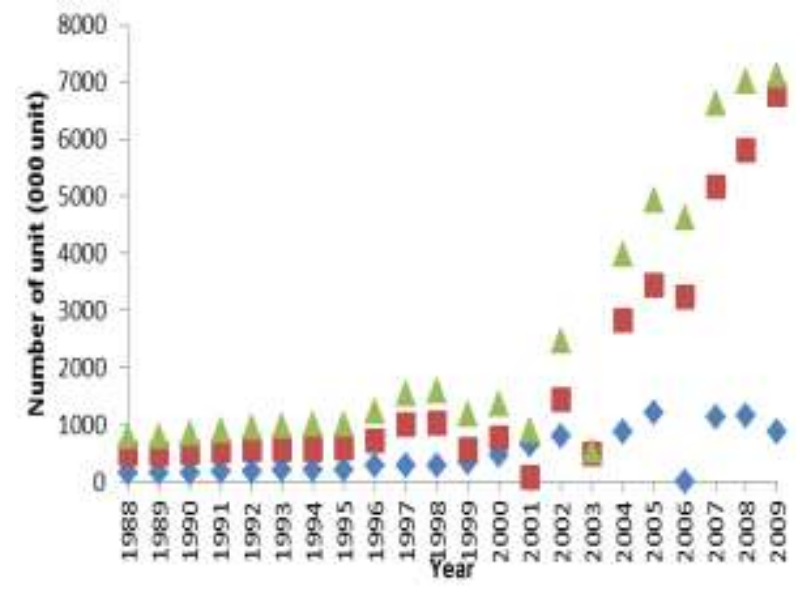

- Automobile (000 unit) a Motorcycle (000 unit) a Total (000 unit)

Figure 3. Number of Automobile in the Province of West Java [28]

\section{Model Estimation of Motorcycle Owner- ship}

In order to develop a model regarding the ownership of motorcycle, data were collected by distributing questionnaire to the user of motorcycle only. The questionnaires were distributed randomly in five regions of Bandung, namely Gede Bage, Ujung Berung, Tegalega, Bojonagara, and Cibeunying. A total of 1000 sets of questionnaires were distributed, 200 sets for each region. The questionnaires were distributed by ten surveyors in ten days, i.e. from September, 22 $2^{\text {nd }}$ until October, $2^{\text {nd }} 2010$ [31].

Table 2 shows respondent's socio-demographic characteristics. Respondent captured in this study was dominated by male ( $80 \%)$, young user in a range between 17-29 years old (65\%) and 30-39 years old (20\%). Most users have senior high school (49\%) and undergraduate (31\%) as their highest education. In this study, respondent are mainly student (52\%), entrepreneur (18\%), and worker in private sector (17\%). Structure of household is young family with father, mother, and child (40\%), which is followed with live alone (15\%). This is in line with respondent's structure of age, which mainly is young user.

Table 1. Estimation Results of Motorcycle Growth in West Jawa Province

\begin{tabular}{|c|c|c|c|c|c|c|c|c|c|}
\hline \multirow{2}{*}{ Model } & \multirow{2}{*}{ Variable } & \multirow{2}{*}{ B } & \multirow{2}{*}{$\mathrm{t}$} & \multirow{2}{*}{ Sig. } & \multicolumn{2}{|c|}{$95 \%$ Confidence Interval for $B$} & \multirow{2}{*}{$\mathrm{R}^{2}$} & \multirow{2}{*}{$\begin{array}{l}\text { p-value } \\
\text { (F-test) }\end{array}$} & \multirow{2}{*}{ MSE } \\
\hline & & & & & Lower Bound & Upper Bound & & & \\
\hline 1 & Population & 0.055 & 4.780 & 0.000 & 0.031 & 0.078 & 0.546 & 0.000 & $3.420 \times 10^{12}$ \\
\hline 2 & GRDP & 0.356 & 14.452 & 0.000 & 0.305 & 0.408 & 0.917 & 0.000 & $6.281 \times 10^{12}$ \\
\hline 3 & Population & -0.008 & -0.928 & 0.366 & -0.025 & 0.010 & 0.920 & 0.000 & \\
\hline & GRDP & 0.388 & 9.203 & 0.000 & 0.299 & 0.476 & & & \\
\hline
\end{tabular}


Table 2. Respondent's Demographic Data

\begin{tabular}{llr}
\hline & \multicolumn{1}{c}{ Variables } & $\begin{array}{c}\text { Proportion } \\
(\%)\end{array}$ \\
\hline Gender & Male & 82.16 \\
& Female & 17.84 \\
\hline Age & 17 years old or younger & 3.52 \\
& 17-29 years old & 64.82 \\
& 30-39 years old & 19.80 \\
& 40-49 years old & 8.94 \\
& 50-59 years old & 2.71 \\
& 60 years old or older & 0.20 \\
\hline Highest & Elementary school or less & 1.80 \\
Education & Junior high school & 7.62 \\
& Senior high school & 48.80 \\
& Diploma & 7.11 \\
& Undergraduate & 31.06 \\
& Graduate & 3.61 \\
\hline Occupation & Student & 52.30 \\
& Civil servant or military & 7.65 \\
& Private & 16.72 \\
& Entrepreneur & 18.13 \\
& Housewife & 3.73 \\
& Retired or other & 1.41 \\
\hline Structure of & Alone & 14.50 \\
Household & Husband and wife only & 8.06 \\
& Husband, wife, and child & 40.18 \\
& Husband, wife, child, and parent & 10.17 \\
& Husband, wife, and parent & 1.71 \\
& Live with relative or friend & 11.58 \\
\hline & & \\
\hline & &
\end{tabular}

Most people who participated in this study have monthly income or allowance less than five million IDR (90\%). Around $40 \%$ and $29 \%$ of respondents have monthly income up to one million IDR and 1 to 2.5 million $\mathrm{IDR}$, respectively. This figures show that the respondents can be categorized as middle to low income. The income category seems to have a relation with the number of motorcycle available in household. Around $47 \%$ and $36 \%$ of the respondent have one unit and two units, respectively. This income condition also reflects the car ownership, where $35 \%$ of respondents have no car and $39 \%$ have one unit. Detail description of economic characteristic of the respondent appears in Table 3.

Table 3. Respondent's Economic Data

\begin{tabular}{llc}
\hline Variables & & Proportion (\%) \\
\hline Monthly Income & less than 0.5 & 12.32 \\
(million IDR) & $0.5-1$ & 29.26 \\
& $1-2.5$ & 28.96 \\
& $2.5-5$ & 18.44 \\
& $5-7.5$ & 6.61 \\
& $7.5-10$ & 1.60 \\
& more than 10 & 2.81 \\
\hline Number of & Not own & 1.51 \\
Motorcycle & One unit & 46.83 \\
& Two units & 35.58 \\
& Three units or more & 16.08 \\
\hline Number of Car & Not own & 35.15 \\
& One unit & 39.38 \\
& Two units & 19.74 \\
& Three units or more & 5.74 \\
\hline
\end{tabular}

Travel characteristic of the respondent is presented in Table 4. Working and education are the main purpose in using motorcycle. Three main reasons for choosing motorcycle are time efficiency (39\%), suitability with need (17\%), and cheap operation cost (14\%). Respondent mainly use motorcycle two times per day (36\%), while one and three times per day have the same percentage (17\%). Motorcycle was used for short to medium trips, i.e. up to eight kilometers, as much as $56 \%$, but $40 \%$ of them used motorcycle for long trip also (more than eight kilometers). Around $75 \%$ of respondents used motorcycle in a range between 15 minutes up to two hours travel.

Table 4. Travel Characteristic using Motorcycle

\begin{tabular}{llr}
\hline & \multicolumn{1}{c}{ Variable } & $\begin{array}{c}\text { Proportion } \\
(\%)\end{array}$ \\
\hline Activity when & sight seeing & 19.36 \\
using & working & 31.09 \\
motorcycle & education & 37.61 \\
& family and friend visits & 2.71 \\
& other & 8.22 \\
\hline Reason to & motorcycle is cheaper than car & 8.71 \\
choose & time efficiency & 38.64 \\
motorcycle & distance efficiency & 5.61 \\
& cheaper in operation cost & 14.01 \\
& suitability with need & 17.32 \\
& only able to buy motorcycle & 4.80 \\
& cheap installment & 2.70 \\
Number of & other & 7.61 \\
motorcycle's & two times & 17.59 \\
usage per day & three times & 35.78 \\
& four times & 16.38 \\
& more than four times & 7.34 \\
Average & less than 1 km & 22.91 \\
distance using & $1-2$ km & 4.91 \\
motorcycle per & $2-4$ km & 10.82 \\
day & $4-6$ km & 17.33 \\
& 6-8 km & 16.03 \\
Average travel & moss than 15 min. & 11.42 \\
time using & $15-30$ min. & 39.48 \\
motorcycle per & 30 min. - 1 hour & 5.41 \\
day & 1 -2 hour & 20.44 \\
& more than 2 hour & 27.35 \\
& & 28.46 \\
& & 18.34 \\
\hline
\end{tabular}

\section{Model Estimation}

For some polychotomous dependent variables, there is a natural order. The ordered logit or probit model is used for this case [32]. In this study, the number of motorcycle owned in each household has an ordered scale. The model is built around a latent regression in the same manner as the binomial probit model [33], as appears in Equation 1.

$y^{*}=x^{\prime} \beta+\varepsilon$ 
In Equation 1, $\mathrm{y}^{*}$ is unobserved. The observation is presented in Equation 2, which is a form of censoring [33]. The $\mu$-s are unknown parameters to be estimated with $\beta$. The responses of the respondents depend on certain measurable factors, $\mathrm{x}$ and certain unobservable factors, $\varepsilon$. It is assumed that $\varepsilon$ is normally distributed across observations [33].

$\mathrm{y}=0 \quad$ if $\mathrm{y}^{*} \leq 0$,

$\mathrm{y}=1 \quad$ if $0<\mathrm{y}^{*} \leq \mu_{1}$,

$\mathrm{y}=2 \quad$ if $\mu_{1}<\mathrm{y}^{*} \leq \mu_{2}$

...,

$\mathrm{y}=\mathrm{J} \quad$ if $\mu_{\mathrm{J}-1} \leq \mathrm{y}^{*}$.

For the same reason as in the binomial probit model (which is the special case of $J=1$ ), it is needed to normalize the mean and variance of $\varepsilon$ to zero and one. The probabilities are presented in Equation 3, while the estimation proceeds by maximum likelyhood [32].

Prob $(\mathrm{y}=0 \mid \mathbf{x})=\boldsymbol{\Phi}(\mathbf{- x} \boldsymbol{\beta})$,

$\operatorname{Prob}(\mathrm{y}=1 \mid \mathbf{x})=\Phi\left(\mu_{1}-\mathbf{x}^{\prime} \beta\right)-\Phi\left(\mathbf{x}^{\prime} \beta\right)$,

$\operatorname{Prob}(\mathrm{y}=2 \mid \mathbf{x})=\Phi\left(\mu_{2}-\mathbf{x}^{\prime} \boldsymbol{\beta}\right)-\Phi\left(\mu_{1}-\mathbf{x}^{\prime} \boldsymbol{\beta}\right)$,

...

$\operatorname{Prob}(\mathrm{y}=\mathrm{J} \mid \mathbf{x})=1-\boldsymbol{\Phi}\left(\mu_{\mathrm{J}-1}-\mathbf{x}^{\mathbf{\prime}} \boldsymbol{\beta}\right)$.

For all the probabilities to be positive,

$0<\mu_{1}<\mu_{2}<\cdots<\mu_{J-1}$

In this study, four different models have been estimated, namely model based on economic, personal, travel, and motorcycle characteristics. The results of parameter estimation are provided in Table 5 to 8 .

To test the goodness-of-fit of the model, the Deviance goodness-of-fit test [34] was applied. The null hypothesis that the model fits will be rejected, if the observed significance level for the goodness-of-fit statistics is small. Good models have large observed significance levels. In Table 5 to 8 , the goodness-of-fit measures are larger than level of significance at 5\%, so it appears that the models fit. Furthermore, the overall test of the null hypothesis of the model that the location coefficients for all variables in the model are 0 , can be based on the change in - 2 log-likelihood when the variables are added to a model that contains only the intercept [34]. From Table 5 to 8 it can be seen that the difference between the two loglikelihood-the chi-square-has an observed significance level much lower than 0.0005 . It means the null hypothesis, that the model without predictors is as good as the model with the predictors, can be rejected. It also means that the models are fit. Besides the estimated coefficient, those tables also present statistical significance of each variable, namely wald, degree of freedom (df), and p-value. The Wald statistic provides the statistical significance for each estimated coefficient, where its interpretation is like $\mathrm{t}$ values for the significance testing of regression coefficients [35].

Table 5 explains the relation between economic characteristics of user's household with the number of motorcycle owned. User with income less than a half million IDR seems to have less motorcycle. People with smaller number of cars owned in household are less likely to own higher number of motorcycle. This finding is in line with the status of house and motorcycle ownership. People who stay in house owned by parent and people who use motorcycle owned by parent and user itself, are more likely to have more motorcycle. This model explains that the owners of motorcycle are they who have medium to low economic status.

The relationship between the numbers of owned motorcycle in household with personal characteris-

Table 5. Parameter Estimates of Motorcycle Ownership based on Economic Characteristics

\begin{tabular}{|c|c|c|c|c|c|}
\hline Variables & Estimate & Std. Error & Wald & $\mathrm{df}$ & Sig. \\
\hline \multicolumn{6}{|l|}{ Threshold } \\
\hline [number of motorcycle $=1$ unit] & -2.525 & 0.213 & 140.483 & 1 & 0.000 \\
\hline [number of motorcycle $=2$ units] & -0.228 & 0.192 & 1.411 & 1 & 0.235 \\
\hline [number of motorcycle $=3$ units] & 0.891 & 0.193 & 21.371 & 1 & 0.000 \\
\hline \multicolumn{6}{|l|}{ Location } \\
\hline Income [ 1 if less than a half million IDR, 0 otherwise] & -0.211 & 0.114 & 3.422 & 1 & 0.064 \\
\hline House ownership [ 1 if owned by parent, 0 otherwise] & 0.269 & 0.082 & 10.882 & 1 & 0.001 \\
\hline Motorcycle ownership [ 1 if owned by user, 0 otherwise] & 0.551 & 0.138 & 16.038 & 1 & 0.000 \\
\hline Motorcycle ownership [ 1 if owned by parent, 0 otherwise] & 0.649 & 0.145 & 19.930 & 1 & 0.000 \\
\hline Number of cars owned [ 1 if not owned, 0 otherwise] & -1.117 & 0.163 & 46.955 & 1 & 0.000 \\
\hline Number of cars owned [ 1 if one unit, 0 otherwise] & -0.842 & 0.161 & 27.443 & 1 & 0.000 \\
\hline Number of cars owned [ 1 if two units, 0 otherwise] & -0.425 & 0.170 & 6.252 & 1 & 0.012 \\
\hline -2LL (0); -2LL (6); [ $\chi^{2} ;$ df.; p-value] & \multicolumn{5}{|c|}{$471.854 ; 344.033 ;[127.820 ; 7 ; 0.000]$} \\
\hline Deviance Goodness-of-Fit [ $\chi^{2} ; \mathrm{df}$.; $\mathrm{p}$-value] & \multicolumn{5}{|c|}{$148.277 ; 122 ; 0.053$} \\
\hline Cox and Snell $\mathrm{R}^{2}$; Nagelkerke $\mathrm{R}^{2} ; \mathrm{McF}$ adden $\mathrm{R}^{2}$ & \multicolumn{5}{|c|}{$0.121 ; 0.137 ; 0.060$} \\
\hline Test of Parallel Lines[ $\chi^{2} ;$ df.; $p$-value] & \multicolumn{5}{|c|}{$41.057 ; 14 ; 0.000$} \\
\hline
\end{tabular}


tics of the users is explained in Table 6. Users with a range of age between 17 to 29 years old and 40 to 49 years old are likely to have more motorcycle. People with undergraduate as their highest education are less likely to have more motorcycles, while people who are students seem to own more motorcycles in their household. The model also shows that the smaller the amounts of monthly income, the smaller number of motorcycle they have. It is also interesting to note that people who own several types of driving license show tendency to have more motorcycles.

Table 7 shows parameter estimates based on travel characteristics. People who make four or more trip per day are likely to own more motorcycle. When people travel short distance, i.e. two kilometers or less, they are less likely to own more motorcycle. It is in line with travel time they spent per day, where people with shorter travel time are more likely to have less motorcycle.

Moreover, this model reveals the decisions to own many motorcycles are also influenced by travel characteristics and not just by price or operating cost. From Table 8, it is found the significant variables of the motorcycle characteristics in explaining the motorcycle ownership. People who spent cost of ownership in a range of one up to one and a half million IDR per year are more likely to have more motorcycle. The model shows that respondents who spend higher operating cost are more likely to have more number of motorcycles at their household. On the other side, cheaper motorcycle seems as less interesting for people to have more motorcycle. It is surprising to know that people seems to have more motorcycle when they can pay by cash.

Table 6. Parameter Estimates of Motorcycle Ownership based on Personal Characteristics

\begin{tabular}{|c|c|c|c|c|c|}
\hline Variables & Estimate & Std. Error & Wald & $\mathrm{df}$ & Sig. \\
\hline \multicolumn{6}{|l|}{ Threshold } \\
\hline [number of motorcycle $=1$ unit] & -2.259 & 0.169 & 178.763 & 1 & 0.000 \\
\hline [number of motorcycle $=2$ units] & -0.019 & 0.137 & 0.018 & 1 & 0.892 \\
\hline [number of motorcycle $=3$ units] & 1.065 & 0.140 & 57.839 & 1 & 0.000 \\
\hline \multicolumn{6}{|l|}{ Location } \\
\hline Age [1 if $17-29$ years old, 0 otherwise] & 0.204 & 0.105 & 3.789 & 1 & 0.052 \\
\hline Age [1 if 40-49 years old, 0 otherwise] & 0.342 & 0.140 & 5.978 & 1 & 0.014 \\
\hline Education [ 1 if undergraduate, 0 otherwise] & -0.204 & 0.084 & 5.962 & 1 & 0.015 \\
\hline Occupation [ 1 is student, 0 otherwise] & 0.471 & 0.105 & 20.064 & 1 & 0.000 \\
\hline Monthly income [ 1 if half million IDR, 0 otherwise] & -0.760 & 0.176 & 18.672 & 1 & 0.000 \\
\hline Monthly income [ 1 if $0.5-1$ million IDR, 0 otherwise] & -0.457 & 0.153 & 8.885 & 1 & 0.003 \\
\hline Monthly income [ 1 if $1-2.5$ million IDR, 0 otherwise] & -0.495 & 0.145 & 11.620 & 1 & 0.001 \\
\hline Monthly income [ 1 if $2.5-5$ million IDR, 0 otherwise] & -0.327 & 0.138 & 5.584 & 1 & 0.018 \\
\hline $\begin{array}{l}\text { Type of driving license [ } 1 \text { if owned more than one type, } 0 \\
\text { otherwise] }\end{array}$ & 0.231 & 0.078 & 8.847 & 1 & 0.003 \\
\hline -2LL (0); -2LL (B); [ $\chi^{2} ; \mathrm{df} . ; \mathrm{p}$-value $]$ & \multicolumn{5}{|c|}{$584.887 ; 509.636 ;[75.251 ; 9 ; 0.000]$} \\
\hline Deviance Goodness-of-Fit [ $\chi^{2} ;$ df.; $p$-value] & \multicolumn{5}{|c|}{$244.569 ; 231 ; 0.258$} \\
\hline Cox and Snell $\mathrm{R}^{2}$; Nagelkerke $\mathrm{R}^{2} ;$ McFadden $\mathrm{R}^{2}$ & \multicolumn{5}{|c|}{$0.074 ; 0.083 ; 0.036$} \\
\hline Test of Parallel Lines [ $\chi^{2} ;$ df.; $p$-value] & \multicolumn{5}{|c|}{$30.940 ; 18 ; 0.029$} \\
\hline
\end{tabular}

Table 7. Parameter Estimates of Motorcycle Ownership based on Travel Characteristics

\begin{tabular}{|c|c|c|c|c|c|}
\hline & Estimate & Std. Error & Wald & $\mathrm{df}$ & Sig. \\
\hline \multicolumn{6}{|l|}{ Threshold } \\
\hline [number of motorcycle $=1$ unit] & -2.535 & 0.130 & 380.749 & 1 & 0.000 \\
\hline [number of motorcycle $=2$ units] & -0.298 & 0.076 & 15.324 & 1 & 0.000 \\
\hline [number of motorcycle $=3$ units] & 0.781 & 0.079 & 97.753 & 1 & 0.000 \\
\hline \multicolumn{6}{|l|}{ Location } \\
\hline Usage per day [ 1 if four times or more, 0 otherwise] & 0.223 & 0.080 & 7.804 & 1 & 0.005 \\
\hline Distance traveled per day [ 1 if $2 \mathrm{~km}$ or less, 0 otherwise] & -0.530 & 0.108 & 24.035 & 1 & 0.000 \\
\hline Travel time per day [ 1 if $0.5-1$ hour, 0 otherwise] & -0.240 & 0.090 & 7.108 & 1 & 0.008 \\
\hline Travel time per day [ 1 if $1-2$ hour, 0 otherwise] & -0.161 & 0.090 & 3.202 & 1 & 0.074 \\
\hline Reason [ 1 if motorcycle is cheaper, 0 otherwise] & -0.579 & 0.102 & 32.568 & 1 & 0.000 \\
\hline Reason [ 1 if motorcycle's operating cost is cheaper, 0 otherwise] & -0.246 & 0.104 & 5.556 & 1 & 0.018 \\
\hline -2LL (0); -2LL (B); [ [ $\chi^{2} ;$ df.; p-value] & \multicolumn{5}{|c|}{$325.958 ; 252.594 ;[73.365 ; 6 ; 0.000]$} \\
\hline Deviance Goodness-of-Fit [ $\chi^{2} ; \mathrm{df}$; $\mathrm{p}$-value $]$ & \multicolumn{5}{|c|}{$87.760 ; 90 ; 0.547$} \\
\hline Cox and Snell $\mathrm{R}^{2} ;$ Nagelkerke $\mathrm{R}^{2} ;$ McFadden $\mathrm{R}^{2}$ & \multicolumn{5}{|c|}{$0.071 ; 0.080 ; 0.034$} \\
\hline Test of Parallel Lines[ $\chi^{2} ;$ df.; $p$-value $]$ & \multicolumn{5}{|c|}{$19.127 ; 12 ; 0.086$} \\
\hline
\end{tabular}


Table 8. Parameter Estimates of Motorcycle Ownership based on Motorcycle Characteristics

\begin{tabular}{|c|c|c|c|c|c|}
\hline & Estimate & Std. Error & Wald & $\mathrm{df}$ & Sig. \\
\hline \multicolumn{6}{|l|}{ Threshold } \\
\hline [number of motorcycle = 1 unit] & -2.524 & 0.159 & 252.253 & 1 & 0.000 \\
\hline [number of motorcycle $=2$ units] & -0.281 & 0.122 & 5.306 & 1 & 0.021 \\
\hline [number of motorcycle $=3$ units] & 0.820 & 0.124 & 43.823 & 1 & 0.000 \\
\hline \multicolumn{6}{|l|}{ Location } \\
\hline Cost of ownership [ 1 if $1-1.5$ million IDR, 0 otherwise] & 0.431 & 0.138 & 9.734 & 1 & 0.002 \\
\hline Operating cost [ 1 if $100 \mathrm{~K}$ IDR or less, 0 otherwise] & -0.213 & 0.099 & 4.587 & 1 & 0.032 \\
\hline Operating cost [ 1 if $200-300 \mathrm{~K}$ IDR, 0 otherwise] & 0.187 & 0.093 & 3.997 & 1 & 0.046 \\
\hline Operating cost [1 if 300-400 K IDR, 0 otherwise] & 0.258 & 0.112 & 5.270 & 1 & 0.022 \\
\hline Price of motorcycle [ 1 if 10 million IDR or less, 0 otherwise] & -0.730 & 0.131 & 31.191 & 1 & 0.000 \\
\hline Price of motorcycle [ 1 if $10-20$ million IDR, 0 otherwise] & -0.354 & 0.112 & 9.930 & 1 & 0.002 \\
\hline Method of payment [ 1 if cash, 0 otherwise] & 0.190 & 0.073 & 6.741 & 1 & 0.009 \\
\hline -2LL (0); -2LL (B); [ [ $\chi^{2} ; \mathrm{df} . ; \mathrm{p}$-value $]$ & \multicolumn{5}{|c|}{$419.811 ; 323.476 ;[96.335 ; 7 ; 0.000]$} \\
\hline Deviance Goodness-of-Fit [ $\chi^{2} ;$ df.; p-value $]$ & \multicolumn{5}{|c|}{$130.492 ; 122 ; 0.283$} \\
\hline Cox and Snell $\mathrm{R}^{2} ;$ Nagelkerke $\mathrm{R}^{2} ;$ McFadden $\mathrm{R}^{2}$ & \multicolumn{5}{|c|}{$0.093 ; 0.105 ; 0.045$} \\
\hline Test of Parallel Lines $\left[\chi^{2} ; \mathrm{df}\right.$; p-value $]$ & \multicolumn{5}{|c|}{$25.131 ; 14 ; 0.033$} \\
\hline
\end{tabular}

\section{Conclusions}

The two simple linear regression models show the significant variables affecting the growth of motorcycles in West Java Province are the population and GRDP. Analysis also shows that for prediction purpose, model with population as dependent variable seems to perform better. Based on model estimates, it can be predicted an increase of 55 units of motorcycle for an addition of 1000 people in West Java. The number of motorcycle in this province will increase by 356,000 units when there is an increase of GRDP as much as one million IDR.

This study also reports four ordered probit models, where statistical measures of goodness-of-fit show the fitness of the models. Model about the relationship between economic characteristics of user's household with the number of motorcycle owned explains that the owners of motorcycle are they who have medium to low economic status. This finding is also supported by the findings found in second model, i.e. model based on personal characteristics. Young users and those who are in their productive age seem to have more motorcycles. The model also found that it should be anticipated the migration from motorcycle user to car's user, as people who owned motorcycle are those who own multiple driving licenses.

Based on model regarding travel characteristics, it reveals the reason to make a decision to own many motorcycles are travel characteristics instead of price or operating cost. It also suggests for more consideration on people's captivity to motorcycle, as motorcycle provides better benefit and higher suitability with people's travel activity. Moreover, the model based on the characteristics of the motorcycle reveals that cheaper motorcycle seems as less interesting for people to have more motorcycles. People also seem to have more motorcycles when they can pay by cash.

This study explains the phenomenon of the increase of motorcycle ownership was not influenced only by economic condition, but also by people's travel behavior and their activity. Thus, it is understandables that people will still select to have more motorcycles seven when they become wealthier, as it is suitable with their travel behavior and activity. This study improves the knowledge regarding motorcycle in Indonesian cities. Most studies in Indonesia focused on social, economic, and demographic characteristics of the motorcyclist or household [4,17,36]. Besides those aspects, this study also elaborates the travel characteristics of the motorcyclist and the characteristics of the motorcycle as well.

\section{Acknowledgment}

The authors express their appreciation to the Ministry of National Education, Republic of Indonesia for providing research fund under the scheme of Competence Research Grant, No. 572/A.A3/KU/2010, January $2^{\text {nd }}, 2010$. Appreciation is also expressed to all parties who have provided assistance in the study process.

\section{References}

1. Badan Pusat Statistik Indonesia, Indonesia dalam Angka 1990-1999, Jakarta, 1990-2011.

2. Kaltheier, R.M., Urban Transport and Poverty in Developing Countries. Analysis and Options for Transport Policy and Planning, Division 44 Enviromental. Management, Water, Energy, Transport, The Deutsche Gesellschaft für Technische Zusammenarbeit GmbH. Eschborn, 2002. 
3. Zukhruf, F., Frazila, R.B., and Wibowo, S.S., Kajian Efektivitas Jalur Sepeda Motor pada Jalan Perkotaan dengan Menggunakan Model Microsimulations, Prosiding Simposium ke-12 Forum Studi Transportasi antar Perguruan Tinggi (FSTPT), 2009, pp. 943-954.

4. Petragradia, R., Hendarto, S., Frazilla, R.B., and Wibowo, S.S., Karakteristik Kepemilikan Sepeda Motor Berdasarkan Karakteristik Rumah Tangga, Prosiding Simposium ke-12 Forum Studi Transportasi antar Perguruan Tinggi (FSTPT), 2009, pp. 1278-1297.

5. Pemerintah Kota Bandung, (Online), (http://www. bandung.go.id/, accessed 29 September 2010), 2010.

6. Sillaparcharn, P., Vehicle Ownership and Trip Generation Modeling a Case Study of Thailand, IATSS Research, 31 (2), 2007, pp. 17-26.

7. Sunggiardi, R. and Putranto, L.S., Discussion on Motorcycle Potential Problems in DKI Jakarta, Prosiding Simposium ke-12 Forum Studi Transportasi antar Perguruan Tinggi (FSTPT), 2009, pp. 789-799.

8. Waluyo, R., Tangkudung, E.S.W., and Tjahjono, T., Studi Mikroskopis Arus Lalulintas Campuran dengan Prosentase Volume Sepeda Motor Sangat Tinggi, Prosiding Simposium ke-12 Forum Studi Transportasi antar Perguruan Tinggi (FSTPT), 2009, pp. 1012-1023.

9. Potoglou, D. and Kanaroglou, P.S., Modeling Car Ownership in Urban Areas: A Case Study of Hamilton, Canada, (Online), Working Paper Series, (http://sciwebserver.science. mcmaster.ca/ cspa/papres/index.html, accessed 3 September 2010), 2006.

10. Dargay, J., Gately, D., and Sommer, M., Vehicle Ownership and Income Growth, Worldwide: 1960-2030, (Online), (http://www.econ.nyu.edu/ dept/courses/gately/DGS_Vehicle\%20 Ownership_ 2007.pdf, accessed 3 September 2010), 2007.

11. Deng, X., Private Car Ownership in China: How Important is the Effect of Income?, (Online) Centre of Regulation and Market Analysis, (http://www.ecosoc.org.au/files/file/TAS/ACE07 /presentations (pdf)/Deng.pdf, accessed 3 September 2010), 2007.

12. Hai, P.K. and Susilo, Y.O., The Motorcycle Ownership Behavior in Hanoi City, Vietnam: How Unique They are Compare to Other Countries?, Proceeding of the Eastern Asia Society for Transportation Studies, 7, 2009.

13. Tuan, V.A. and Shimizu, T., Modeling of Household Motorcycle Ownership Behavior in Hanoi City, Journal of the Eastern Asia Society for Transportation Studies, 6, 2005, pp. 1751- 1765.
14. Zhang, J., Norton, R., Tang, K.C., Lo, S.K., Jiatong, Z., and Wenkui, G., Motorcycle Ownership and Injury in China, International Journal of Injury Control and Safety Promotion, 11(3), 2004, pp. 159-163.

15. Hsu, T.P., Sadullah, A.F.M., and Dao, N.X., $A$ Comparison Study on Motorcycle Traffic Development in Some Asian Countries-Case of Taiwan, Malaysia, and Vietnam, (Online) (http://www.easts.info/activities/icra/2001/ICRAc omparisonStudyMotorcycleDevelopment.pdf, accessed 18 September 2010), 2003.

16. Hsu, T-P., Tsai, C-C., and Lin, Y-J., Comparative Analysis of Household Car and Motorcycle Ownership Characteristics, Journal of the Eastern Asia Society for Transportation Studies, 7, 2007, pp. 105-115.

17. Putranto, L.S., Montgomery, F., and Muller, S.G., Characteristics of Private Car and Motorcycle Ownership in Indonesia, Proceeding of the Eastern Asia Society for Transportation Studies, 6, 2007.

18. Kurniawan, M., Sepeda Motor, Sarana Transportasi Termurah, (Online), (http://megapolitan. kompas.com/read/2010/02/17/02433866/Sepeda. Motor. Sarana. Transportasi. Termurah, accessed 29 September 2010), 2010.

19. Ingram, G.K. and Liu, Z., Motorization and the Provision of Roads in Countries and Cities, Policy Research Working Paper, Brookings Institution Press, Washington, D.C., 1997.

20. Lubis, H.A.R.S., Motorcycle Growth and Its Impacts to Urban Transportation, Proceeding of the Eastern Asia Society for Transportation Studies, 7, 2009.

21. Leong, L.V. and Sadullah, A.F.M., A Study on the Motorcycle Ownership: A Case Study in Penang State, Malaysia, Journal of the Eastern Asia Society for Transportation Studies, 7, 2007.

22. Senbil, M., Zhang, J., and Fujiwara, A., Motorcycle Ownership and Use in Jabotabek (Indonesia) Metropolitan Area, Discussion Paper Series Vol.2006-3, Graduate School of International Development and Cooperation, Hiroshima University, Hiroshima, 2006.

23. The World Bank, Sustainable Transport: Priorities for Policy Reform, Development in Practice, Washington, D.C., 1996, pp. 27-28.

24. Ingram, G.K. and Liu, Z., Determinants of Motorization and Road Provision, In GomezIbáñes, J., Tye, W.B., and Winston, C. (Eds.), Essay in Transportation Economics and Policy, A Handbook in Honor of John R. Meyer, Brookings Institution Press, Washington, D.C., 1999. 
25. Gentile, L., Understanding Motorcyclist and How They Ride, (Online), (http://www.suite101. com/ content/understanding-motorcyclists, accessed 27 September 2010), 2009.

26. Wedagama, D.M.P., Estimating the Influence of Accident-related Factors on Motorcycle Fatal Accidents using Logistic Regression (Case Study: Denpasar-Bali), Civil Engineering Dimension, 12(2), 2010, pp. 106-112.

27. Freudenheim, E., Motorcycle Accidents Can Cause Emotional, Mental Problems, (Online) (http:// www.suite101.com/content/motorcycle-accidentscan-cause emotional-mental-problems, accessed 27 September 2010), 2010.

28. Badan Pusat Statistika Propinsi Jawa Barat, Bandung Dalam Angka, Bandung, 2009.

29. Acharya, S.R., Modeling Dynamics of Car Ownership and Urban Density for Developing Cities, Proceeding of the Eastern Asia Society for Transportation Studies, 7, 2009.

30. Lauw, B.Z., Permodelan Pertumbuhan Sepeda Motor di Provinsi Jawa Barat, Bachelor Thesis, Department of Civil Engineering, Faculty of Engineering, Parahyangan Catholic University, Bandung, 2011.
31. Hendy, H., Karakteristik Kepemilikan dan Penggunaan Sepeda Motor di Kota Bandung, Bachelor Thesis, Department of Civil Engineering, Faculty of Engineering, Parahyangan Catholic University, Bandung, 2011.

32. Kennedy, P., A Guide to Econometrics, Fifth Edition. The MIT Press. Cambridge, Massachusetts, 2003.

33. Greene, W.H., Econometric Analysis, Fifth Edition, Pearson Education, Inc., Delhi, 2003.

34. Norušis, M., Ordinal Regression, Chapter 4. SPSS 14.0 Advanced Statistical Procedures Companion. (Online) (http://www.norusis.com/ pdf/ASPC_v13.pdf_, accessed 3 July 2006) 2006.

35. Hair, J.F., Black, W.C., Babin, B.J., Anderson, R.E., and Tatham, R.L., Multivariate Data Analysis, Sixth Edition, Pearson Education, Inc., New Jersey, 2006.

36. Wedagama, D.M.P., The Analysis of Household Car and Motorcycle Ownerships using Poisson Regression (Case Study: Denpasar-Bali), Jurnal Teknik Sipil, 16(2), 2009, pp. 103-112. 